\title{
Cytokine-dependent Long-Term Culture of Highly Enriched Precursors of Hematopoietic Progenitor Cells from Human Bone Marrow
}

\author{
John Brandt, Edward F. Srour, Koen van Besien, Robert A. Briddell, and Ronald Hoffman \\ Division of Hematology/Oncology and Indiana Elks Cancer Research Center, \\ Indiana University School of Medicine, Indianapolis, Indiana 46202
}

\begin{abstract}
Human marrow cells positive for the CD34 antigen but not expressing HLA-DR, CD15, or CD71 antigens were isolated. In a liquid culture system supplemented with 48 -hourly additions of recombinant interleukins IL-1 $\alpha$, IL-3, IL-6, or granulocyte/macrophage colony-stimulating factor (GM-CSF), these cells were capable of sustaining in vitro hematopoiesis for up to eight weeks. The establishment of an adherent cell layer was never observed. Cultures containing no exogenous cytokine produced clonogenic cells for only 1 wk. IL-1 $\alpha$ and IL-6 were alone able to support hematopoiesis for 2 or 3 wk. Cells maintained with GM-CSF proliferated and contained assayable colony-forming cells for 3 or 4 wk, while maximal cellular expansion and generation of assayable progenitor cells occurred in the presence of IL-3 for 4-5 wk. When IL-3 was combined with IL-1 $\alpha$ or IL-6, hematopoiesis was sustained for 8 wks. Basophil numbers were markedly increased in the presence of IL-3. These studies indicate that marrow subpopulations can sustain hematopoiesis in vitro in the presence of repeated additions of cytokines. We conclude that a major function of marrow adherent cells in long-term cultures is that of providing cytokines which promote the proliferation and differentiation of primitive hematopoietic cells. (J. Clin. Invest. 1990. 86:932-941.) Key words: cell sorting • differentiation • growth factors • proliferation • stem cells
\end{abstract}

\section{Introduction}

Human bone marrow is composed of heterogeneous populations of hematopoietic precursor and progenitor cells. A variety of in vitro clonal assay systems have been utilized to detect such progenitor cells (1-4). An extensive body of information is currently available which indicates the existence of more primitive hematopoietic cells termed stem cells (5-10). Stem cells have not only the ability to supply mature hematopoietic cells for prolonged periods of time but also are able to generate a continuous supply of additional stem cells, a process referred to as self-renewal $(11,12)$.

Recently, pure populations of murine hematopoietic stem cells have been isolated which are capable of rescuing lethally irradiated mice and reconstituting all hematopoietic and lymphoid lineages in survivors $(5,6)$. Detection and eventual iso-

Address reprint requests to Dr. Hoffman, 975 West Walnut Street, IB 442, Indianapolis, IN 46202-5121.

Received for publication 14 February 1990 and in revised form 1 May 1990.

\section{J. Clin. Invest.}

(C) The American Society for Clinical Investigation, Inc. $0021-9738 / 90 / 09 / 0932 / 10 \quad \$ 2.00$

Volume 86, September 1990, 932-941 lation of the human equivalent of a pluripotent hematopoietic stem cell have been hindered due in part to the lack of availability in humans of a suitable assay system for this cell. Primitive hematopoietic progenitor cells capable in vitro of producing colonies composed of blast cells (CFU-B1) have, however, been detected in human umbilical cord blood and normal human bone marrow (7-10). These cells possess many of the features of stem cells in that they are capable of both self-renewal and commitment to various hematopoietic lineages. Preliminary phenotypic characterization of the human CFU-B1 has already been accomplished using monoclonal antibody staining and fluorescence-activated cell sorting (10). Since assessment of the self-renewal capacity of the CFU-B 1 is dependent on the tedious replating of individual blast cell colonies, routine application of this assay has proven difficult.

An alternative in vitro methodology that has been utilized to study the behavior of primitive hematopoietic elements has been the long-term marrow culture system originally described by Dexter et al. (13). This system requires the preestablishment of a marrow adherent cell layer composed primarily of marrow stromal cells. This in vitro model has been utilized to study stem cell proliferation and differentiation under conditions where close-range interactions with marrow stromal elements are presumably required. Stromal cell-dependent hematopoiesis has been postulated to result from either direct contact between stromal and stem cells or progenitor cells (14), from the trophic effects of the stromal cell-derived extracellular matrix (15), or from stromal cell secretion of hematopoietic growth factors (16-18). Difficulties in defining the relative contributions of these proposed functions have resulted from lack of availability of both pure populations of individual stromal cell types and primitive hematopoietic cellular elements. Recently, a growing number of recombinant cytokines that affect hematopoietic cellular differentiation have become available (19). We have developed a suspension system to study the effects of these cytokines on purified populations of primitive hematopoietic progenitor cells. These long-term marrow culture systems have been established in the absence of a preestablished adherent cell layer. The information presented here provides new insight into factors that control the development of pluripotential hematopoietic cells.

\section{Methods}

Cell separation techniques. Bone marrow aspirates were collected from the posterior iliac crests of normal volunteers after informed consent was obtained according to the guidelines of the Human Investigation Committee of the Indiana University School of Medicine. Low-density mononuclear bone marrow (LDBM) ${ }^{1}$ cells were obtained by density

1. Abbreviations used in this paper: GM-CSF, granulocyte/macrophage colony-stimulating factor; HPP-CFC, high proliferative potential colony-forming cell; LDBM, low-density mononuclear bone marrow (cell). 
centrifugation of the heparinized marrow over Ficoll-Paque (Pharmacia Fine Chemicals, Piscataway, NJ) at $500 \mathrm{~g}$ for $25 \mathrm{~min}$. LDBM cells were suspended in PBS-EDTA (PBS, pH 7.4, containing 5\% FBS, $0.01 \%$ EDTA wt/vol, and $1.0 \mathrm{~g} /$ liter D-glucose) and injected into an elutriator system at $10^{\circ} \mathrm{C}$ at a rotor speed of $1,950 \mathrm{rpm}$ using a JA-17 rotor and standard separation chamber (Beckman Instruments, Inc., Palo Alto, CA). A fraction of the LDBM eluted at a flow rate of 12-14 $\mathrm{ml} / \mathrm{min}$ (FR 12-14), enriched for hematopoietic precursors, was collected as previously described (10).

Two- and three-color cell sorting. FR 12-14 cells were incubated with mouse monoclonal anti-HPCA-1 (CD34) of the $\mathrm{IgG}_{1}$ subclass (Becton Dickinson Immunocytometry Systems, San Jose, CA), washed, and stained with Texas red-conjugated, subclass-specific goat anti-mouse IgG $_{1}$ (Southern Biotechnology Associates, Inc., Birmingham, AL). Cells were next incubated with mouse serum to block any unbound active sites on the second-step antibody. Cells were finally stained with phycoerythrin-conjugated mouse anti-HLA-DR either alone or in combination with FITC-conjugated CD33 (My9, Coulter Immunology, Hialeah, FL), CD15 (Leu-M1), or CD71 (transferrin receptor) (Becton Dickinson Immunocytometry Systems). CD15 is present on cells of the granulocytic and monocytic lineages, and an anti-CD15 monoclonal antibody was employed in the hope of eliminating these cellular components from the cell populations (20). CD71 is present on actively proliferating cells and an anti-CD71 antibody was utilized to separate actively proliferating cells from more quiescent marrow elements (21). Controls consisted of the corresponding isotype-matched, nonspecific myeloma proteins used in parallel with the staining monoclonal antibodies. Cells were stained at a concentration of $2 \times 10^{7} / \mathrm{ml}$ and washed after each step in $1 \%$ BSA in PBS. A temperature of $4^{\circ} \mathrm{C}$ was maintained throughout the procedure.

Immediately after staining, cells were sorted on a Coulter Epics 753 dual-laser flow cytometry system (Coulter Electronics, Inc., Hialeah, FL). Texas red was excited by 590 -nm light emitted from a rhodamine 6G dye laser. FITC and phycoerythrin were excited using the $488 \mathrm{~nm}$ wavelength from a dedicated 6-W argon laser. Sorting windows were first established for forward angle light scatter (FALS) and Texas red fluorescence. Positivity for each fluorochrome was defined as fluorescence $>99 \%$ of that of the controls. Cells were next gated on the presence or absence of detectable HLA-DR-phycoerythrin and CD33FITC, CD15-FITC, or CD71-FITC.

Hematopoietic growth factors. All cytokines were obtained from the Genzyme Corp., Boston, MA. Recombinant IL- $1 \alpha$ and IL-3 each had a specific activity of $10^{8} \mathrm{CFU} / \mathrm{mg}$ protein, while that of IL-6 was $10^{7}$ and granulocyte/macrophage colony-stimulating factor (GMCSF) $5 \times 10^{7} \mathrm{CFUc} / \mathrm{mg}$ protein.

Hematopoietic progenitor cell assays. Cells were suspended at various concentrations in 35-mm plastic tissue culture dishes (Costar Data Packaging, Cambridge, MA) containing $1 \mathrm{ml}$ of $30 \% \mathrm{FBS}, 5 \times 10^{-5} \mathrm{M}$ 2-mercaptoethanol, $1 \mathrm{U}$ human purified erythropoietin $(50 \mathrm{U} / \mathrm{mg}$ protẹin, Toyobo Co. Ltd., Osaka, Japan), 50 U GM-CSF, and $1.1 \%$ methylcellulose in Iscove's modified Dulbecco's medium. The cultures were incubated at $37^{\circ} \mathrm{C}$ in a $100 \%$ humidified atmosphere of $5 \% \mathrm{CO}_{2}$ in air. After $14 \mathrm{~d}$, erythropoietic bursts (BFU-E), granulocyte-macrophage (CFU-GM), and mixed lineage (CFU-GEMM) colonies were scored in situ on an inverted microscope using standard criteria for their identification (10).

High proliferative potential colony-forming cell (HPP-CFC)-derived colonies were enumerated after $28 \mathrm{~d}$ in culture according to the recently published criteria of $\mathrm{McNiece}$ and co-workers (22). The human HPP-CFC-derived colony is a late-appearing, very large $(0.5$ $\mathrm{mm}$ or more in diameter) colony composed primarily of granulocytes with a lesser number of monocytes; cell numbers frequently exceed 50,000 .

Cells removed from suspension cultures were assayed for CFUmegakaryocyte (CFU-MK) colonies using the serum-depleted method described in detail by Bruno et al. (23). $5 \times 10^{3}$ cells per point were suspended in a 1 -ml serum-substituted fibrin clot with $100 \mathrm{U}$ of IL-3 in $35-\mathrm{mm}$ culture dishes and incubated at $37^{\circ} \mathrm{C}$ in a $100 \%$ humidified atmosphere containing $5 \% \mathrm{CO}_{2}$ in air. At $18-24 \mathrm{~d}$, cultures were fixed in situ and stained using rabbit anti-human platelet glycoprotein antisera, and fluorescein-conjugated goat $\mathrm{F}\left(\mathrm{ab}^{\prime}\right)_{2}$-specific anti-rabbit IgG (Tago, Inc., Burlingame, CA) and megakaryocyte colonies were enumerated on a Zeiss fluorescence microscope (Carl Zeiss, Inc., New York, NY). A positive colony was defined as a cluster of three or more fluorescent cells.

Long-term marrow cultures. Plastic 35-mm tissue culture dishes were seeded with $2 \times 10^{6} \mathrm{LDBM}$ cells in $1 \mathrm{ml}$ of Iscove's with $10 \%$ FBS and $2 \times 10^{-5} \mathrm{M}$ methylprednisolone. Cultures were incubated at $37^{\circ} \mathrm{C}$ in $100 \%$ humidified $5 \% \mathrm{CO}_{2}$ in air and fed weekly by total replacement of media. Stromal cells were confluent by 4-6 wk. The stromal cultures were then irradiated with 1,500 rad, the media were replaced, and the cultures were inoculated with $5 \times 10^{3}$ sorted bone marrow cells from autologous donors. The media in these cultures were removed at $7-10-d$ intervals and replaced with fresh media. Suspended, nonadherent cells were then counted and assayed for progenitors.

Long-term suspension cultures. Plastic 35-mm tissue culture dishes containing $1 \mathrm{ml}$ of Iscove's with $10 \%$ FBS were inoculated with $5 \times 10^{3}$ cells obtained by sorting and incubated at $37^{\circ} \mathrm{C}$ in $100 \%$ humidified $5 \% \mathrm{CO}_{2}$ in air. At this time, and every $48 \mathrm{~h}$ thereafter, cultures received nothing (1\% BSA/PBS), $2.5 \mathrm{U} / \mathrm{ml} \mathrm{IL-1} \alpha, 50 \mathrm{U} / \mathrm{ml} \mathrm{IL-3,} 75 \mathrm{U} / \mathrm{ml} \mathrm{IL-6,}$ 12.5 U/ml GM-CSF, or combinations of the above. At 7-d intervals, cultures were demi-depopulated by removal of one-half the culture volume which was replaced with fresh media. Cells in the harvested media were counted, transferred to slides for staining and morphological examination, and assayed for various progenitor cells.

Cell cycle analysis. DNA content and distribution was determined flow cytometrically using propidium iodide by a modified method of Vindelov et al. (24). Briefly, cells were suspended in equal volumes of staining buffer $(0.1 \mathrm{mg} / \mathrm{ml}$ propidium $+0.6 \% \mathrm{NP}-40$ in PBS $)$ and RNAse $(2 \mathrm{mg} / \mathrm{ml}$ in PBS, Boehringer Mannheim Biochemicals, Indianapolis, IN) for a total volume of 500-800 $\mu$, agitated, and incubated on ice for $30 \mathrm{~min}$. Analysis was performed on a FACScan using the SFIT software program (Becton Dickinson Immunocytometry Systems) for determination of $\mathrm{G}, \mathrm{S}$, and $\mathrm{G}_{2}+\mathrm{M}$ fractions; $5 \times 10^{3}$ cells were analyzed per determination.

\section{Results}

$\mathrm{CD}^{+} 4^{+} \mathrm{DR}^{+}$and $\mathrm{CD} 4^{+} \mathrm{DR}^{-}$marrow cells were seeded at a concentration of $5 \times 10^{3}$ cells $/ \mathrm{ml}$ onto preestablished, irradiated, autologous marrow adherent cell layers. The $\mathrm{CD} 34^{+} \mathrm{DR}^{+}$population produced the highest number of nonadherent cells (Fig. $1 a$ ) and assayable CFU-GM (Fig. $1 b$ ) after 10 days of culture. All subsequent data revealed, however, that the DR-negative cells were more effective in sustaining hematopoietic proliferation as measured by total cell production over the next forty days of observation (Fig. $1 a$ ). Cumulative production of assayable progenitor cells was also far greater when $\mathrm{CD}^{+} 4^{+} \mathrm{DR}^{-}$cells were used as a recharge inoculum than when $\mathrm{CD}^{+} 4^{+} \mathrm{DR}^{+}$cells were utilized (Fig. 1 b). Control cultures receiving no recharge with sorted cells released smaller numbers of cells into the supernate which upon examination were macrophages; no assayable progenitor cells of any kind were produced by these cultures. In similar experiments with media replacement occuring every $7 \mathrm{~d}, \mathrm{CD}^{+} 4^{+} \mathrm{DR}^{-}$-derived CFU-GM output exceeded that of $\mathrm{CD}^{2} 4^{+} \mathrm{DR}^{+}$cells by day 14 (data not shown). In all studies, small numbers of BFU-E were generated over the first 2-3 wk by both marrow subpopulations. Cell cycle analysis of the marrow subpopulations obtained at various stages of cell separation demonstrated that over $97 \%$ of the $C D 34^{+} \mathrm{DR}^{-}$cells resided in $\mathrm{G}_{0}+\mathrm{G}_{1}$ stage while higher percentages of LDBM, FR12-14, and 

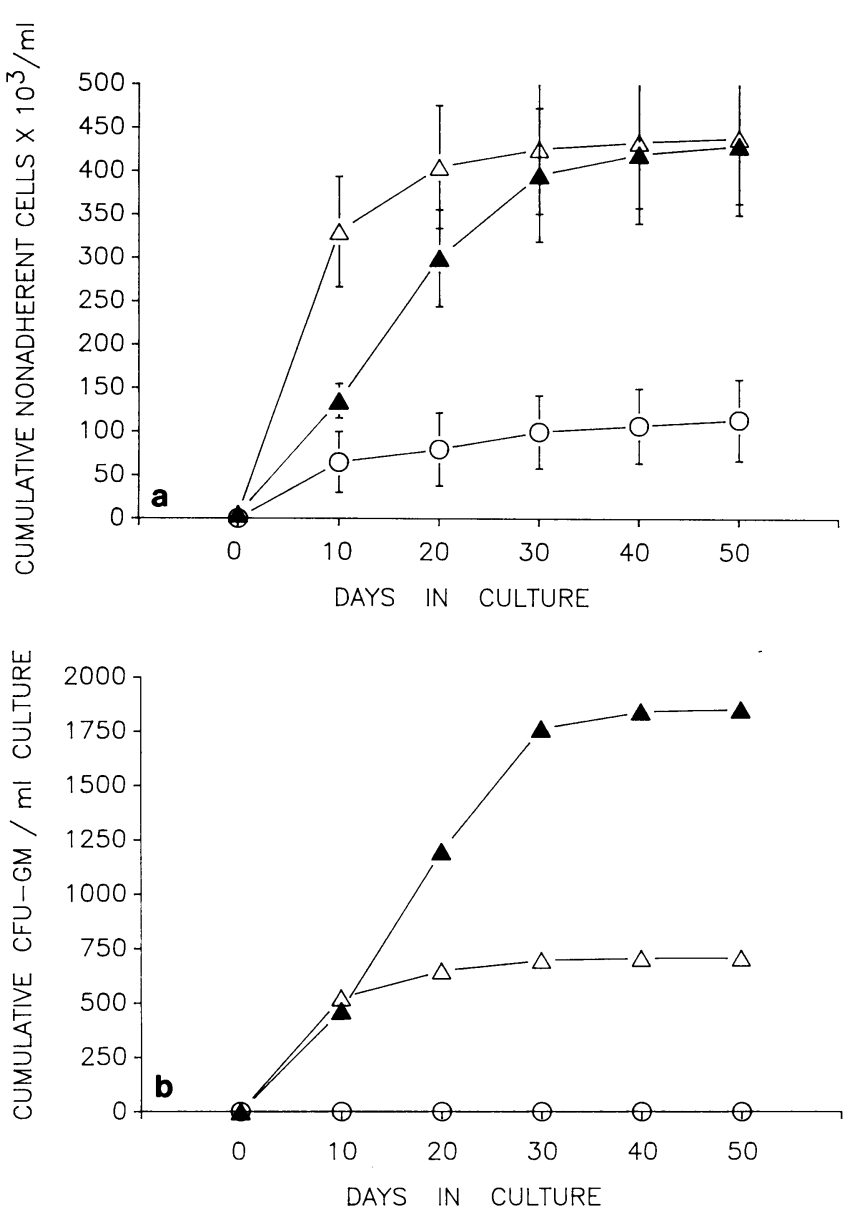

Figure 1. (a) Cumulative supernatant cell counts of 4-wk-old, irradiated stromal cultures re-seeded with no cells $(0)$, or autologous $\mathrm{CD}^{+} 4^{+} \mathrm{DR}^{+}(\Delta)$ or $\mathrm{CD}^{+} 4^{+} \mathrm{DR}^{-}(\Delta)$ cells at $5 \times 10^{3} / \mathrm{ml}$. Each point represents the mean $\pm \mathrm{SD}$ of duplicate cultures. (b) Cumulative production of CFU-GM by CD34 ${ }^{+} \mathrm{DR}^{+}$or $\mathrm{CD} 34^{+} \mathrm{DR}^{-}$cells seeded onto autologous, irradiated stromal cultures. Each point represents the mean number of CFU-GM assayed \pm SD of duplicate cultures (all standard deviation values fall within symbol areas).

$\mathrm{CD} 4^{+} \mathrm{DR}^{+}$fractions were in more active phases of the cell cycle (Table I).

Multiparameter sorting was utilized in an effort to further phenotype those $\mathrm{CD} 34^{+} \mathrm{DR}^{-}$cells responsible for long-term in vitro hematopoiesis. Virtually all cells residing in the CD34 ${ }^{+} \mathrm{DR}^{-}$population failed to express the CD33 antigen (Fig. $2 a$ ). Anti-CD15 and anti-CD71 were next examined as sorting probes (Fig. 2, $b$ and $c$ ). Morphological analysis of these sorted populations are shown in Table II. Well over $90 \%$ of $\mathrm{CD}_{4}{ }^{+} \mathrm{DR}^{-} \mathrm{CD} 15^{-}$and $\mathrm{CD} 34^{+} \mathrm{DR}^{-} \mathrm{CD} 71^{-}$cells appeared as hematopoietic blasts showing no evidence of characteristics indicating lineage commitment; the subpopulations expressing CD15 or CD71 contained more differentiated cell types. Table III illustrates the progenitor cell content of these various cell populations. It can be seen that the $\mathrm{CD} 34^{+} \mathrm{DR}^{-} \mathrm{CD} 33^{+}$and $\mathrm{CD} 34^{+} \mathrm{DR}^{-} \mathrm{CD}_{15}{ }^{+}$populations contained few assayable progenitors while significant numbers were contained in the other cell fractions. The overwhelming majority of BFU-E present in $\mathrm{CD} 34^{+} \mathrm{DR}^{-}$cells resided in the $\mathrm{CD} 34^{+} \mathrm{DR}^{-} \mathrm{CD} 71^{+}$population. It was notable that both $\mathrm{CD} 34^{+} \mathrm{DR} \mathrm{R}^{-} \mathrm{CD} 15^{-}$and
CD34 ${ }^{+} \mathrm{DR}^{-} \mathrm{CD}_{71} 1^{-}$cells contained HPP-CFC while those $\mathrm{CD}^{+} 4^{+} \mathrm{DR}^{-}$fractions expressing either CD15 or CD71 did not.

A liquid culture system supplemented with repeated 48-hourly cytokine additions was utilized to further study these cell populations. Total cell production by both $\mathrm{CD} 34^{+}$ $\mathrm{DR}^{-} \mathrm{CD} 15^{-}$and $\mathrm{CD} 34^{+} \mathrm{DR}^{-} \mathrm{CD} 71^{-}$cells is shown in Tables IV and V while assayable CFU-GM in these cultures over time are recorded in Tables VI and VII. In the absence of exogenous cytokines, total cell numbers declined over a 2-wk period and assayable CFU-GM persisted for only 1 or $2 \mathrm{wk}$. The repeated addition of IL- $1 \alpha$ did not significantly enhance total cell production or generation of CFU-GM by either $\mathrm{CD}^{2} 4^{+}$ $\mathrm{DR}^{-} \mathrm{CD} 15^{-}$or $\mathrm{CD} 34^{+} \mathrm{DR}{ }^{-} \mathrm{CD} 71^{-}$cells. IL-6 did not alter total cell numbers or numbers of assayable CFU-GM in cultures initiated with $\mathrm{CD}_{34}{ }^{+} \mathrm{DR}^{-} \mathrm{CD} 71^{-}$cells. By contrast, IL-6 increased total cell numbers over sevenfold by week 3 by $\mathrm{CD} 34^{+} \mathrm{DR}^{-} \mathrm{CD} 15^{-}$initiated cultures but did not appreciably extend the interval over which CFU-GM were detected. In both sets of experiments, GM-CSF promoted increased total cell production for $6 \mathrm{wk}$, by which time cell numbers represented 20-80 times the number present in the initial seeding populations. Assayable CFU-GM persisted for 3-4 wk and cumulatively surpassed those assayable in the initial populations. The single most effective cytokine in terms of promoting cellular expansion, increasing the number of CFU-GM, and lengthening the duration of time over which CFU-GM were assayable was IL-3. Both $\mathrm{CD} 34^{+} \mathrm{DR}^{-} \mathrm{CD} 15^{-}$and $\mathrm{CD} 34^{+}$ $\mathrm{DR}^{-} \mathrm{CD} 71^{-}$cells experienced 200 -fold increases in cell numbers by day 28 , and, after 1 or $2 \mathrm{wk}$ in culture, contained equal or slightly greater numbers of CFU-GM than present in the initial inoculi. Assayable progenitors were produced for 4-5 wk in the system when maintained with IL-3, and viable cell counts remained high at $8 \mathrm{wk}$. IL- $1 \alpha$ or IL- 6 prolonged and enhanced these effects when added in combination with IL-3. CFU-GM were assayable after $8 \mathrm{wk}$ in suspension culture after continued treatment with these two cytokine combinations. No adherent cell layer was established in any of the suspension cultures over the 8-wk period of observation.

In a separate experiment, $\mathrm{CD} 34^{+} \mathrm{DR} \mathrm{R}^{-} \mathrm{CD} 71^{-}$cells were grown in this suspension culture system in the presence of a combination of both IL-3 and IL-6 and assayed for CFU-MK from days 7 through 28 of culture. CFU-MK were detected over this 28 -d period (Table VIII). Utilizing this IL-3/IL-6 cytokine combination, the ability of $\mathrm{CD} 34^{+} \mathrm{DR} \mathrm{R}^{-} \mathrm{CD} 15^{+}$and

Table I. Cell Cycle Analysis of Human Bone Marrow Fractions

\begin{tabular}{lrccr}
\hline \multicolumn{1}{c}{ Phase } & LDBM & FR12-14 & CD34 $^{+} \mathrm{DR}^{+}$ & $\mathrm{CD}^{\ddagger} 4^{+} \mathrm{DR}$ \\
\hline \multicolumn{5}{c}{ percentage of cell population* } \\
$\mathrm{G}_{0}+\mathrm{G}_{1}$ & 88.2 & 92.1 & 96.0 & 97.5 \\
$\mathrm{~S}$ & 10.2 & 7.0 & 3.8 & 2.5 \\
$\mathrm{G}_{2}+\mathrm{M}$ & 1.6 & 0.9 & 0.1 & 0.0
\end{tabular}

DNA distribution was determined flow cytometrically by propidium iodide staining of cell preparations and analysis on a FACScan using SFIT program.

$* 5 \times 10^{3}$ cells per sample were analyzed.

₹ LDBM was fractionated by counterflow centrifugal elutriation; cells eluted at a flow rate of $12-14 \mathrm{ml} / \mathrm{min}$ at a rotor speed of $1,950 \mathrm{rpm}$ using an elutriation system with standard separation chamber. 

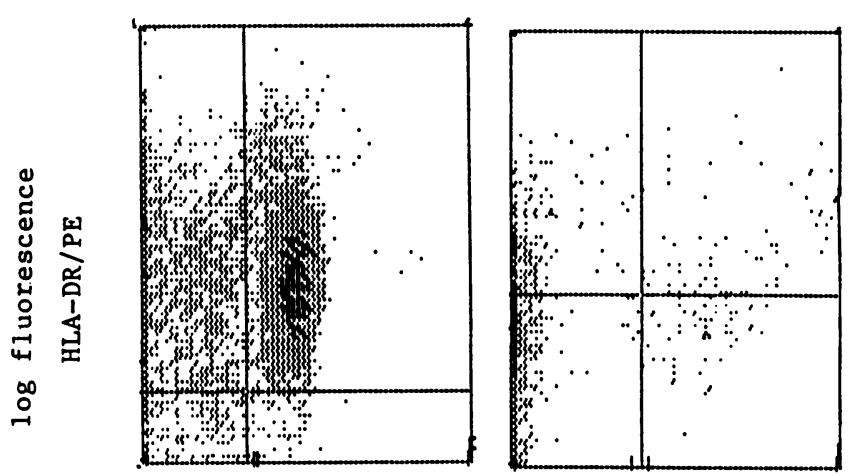

a

$\log$ fluorescence

b

CD15/FITC

$\log$ fluorescence

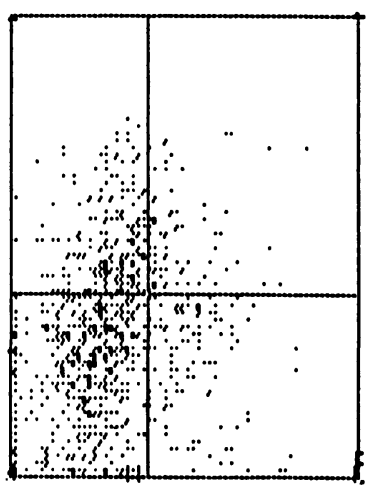

C

CD71/FITC

$\log$ fluorescence
Figure 2. Two-parameter histograms representing density distributions of (a) CD33 vs. HLA-DR, (b) CD15 vs. HLA-DR, and (c) CD11 vs. HLA-DR by human marrow cells. FR 12-14 marrow cells were gated on forward angle light scatter and gates were set for cells positively stained by CD34 antibody second-step conjugated to Texas red. Cells positive for CD34 were analyzed for evidence of staining by PE-conjugated anti-HLA-DR and FITC-conjugated anti-CD33, CD15, or CD71. Vertical bars represent positivity for HLA-DR and horizontal bars positivity for CD33, CD15, or CD71 defined as fluorescence above that of $99 \%$ of isotype-matched nonspecific myeloma proteins used in parallel with the staining monoclonal antibodies.

$\mathrm{CD} 34^{+} \mathrm{DR}^{-} \mathrm{CD} 71^{+}$cells to sustain long-term hematopoiesis was compared to that of the $\mathrm{CD} 34^{+} \mathrm{DR}^{-} \mathrm{CD} 15^{-}$and $\mathrm{CD} 34^{+} \mathrm{DR}^{-} \mathrm{CD} 71^{-}$fractions (Table IX). Both the CD15-positive and CD71-positive cells failed to generate CFU-GM after 2 wk, and the CD71-positive population, which initially included the overwhelming majority of BFU-E, failed to produce assayable BFU-E after only $7 \mathrm{~d}$ in culture.

Morphological analysis of the cells in these suspension cultures during the period of observation revealed changes in the cellular composition of the populations following the addition of various cytokines (Tables X and XI). IL- $1 \alpha$ - and IL-6-containing cultures behaved very similarly to the control samples. Cultures to which no cytokines were added were composed of 90-100\% blasts after $1 \mathrm{wk}$; the $\mathrm{CD} 34^{+} \mathrm{DR}^{-} \mathrm{CD} 15^{-}$cells did not survive $2 \mathrm{wk}$ in the absence of cytokine whereas the $\mathrm{CD} 34^{+} \mathrm{DR}^{-} \mathrm{CD}_{71^{-}}$initiated cultures were composed of $40 \%$ blasts and $60 \%$ monocytes by week 2 . Cultures receiving IL- $1 \alpha$ had a similar cellular composition. IL-6 facilitated some differentiation to the granulocytic series by both cell populations; the $\mathrm{CD} 34^{+} \mathrm{DR}{ }^{-} \mathrm{CD} 15^{-}$cells produced a significant number of mature granulocytic elements by week 2. GM-CSF, as well as IL-3, reduced the percentage of blasts in these suspension cultures appreciably by day 7. GM-CSF-containing cultures of

$\mathrm{CD} 34^{+} \mathrm{DR}^{-} \mathrm{CD} 15^{-}$and $\mathrm{CD} 34^{+} \mathrm{DR}^{-} \mathrm{CD} 71^{-}$cells consisted primarily of metamyelocytes through $4 \mathrm{wk}$, with a shift to monocytes occurring by week 6 .

IL-3 was unique in that, at $3 \mathrm{wk}$, suspension cultures initiated by either $\mathrm{CD} 34^{+} \mathrm{DR}^{-} \mathrm{CD} 15^{-}$or $\mathrm{CD} 34^{+} \mathrm{DR}{ }^{-} \mathrm{CD} 71^{-}$cells were composed of $48 \%$ basophils in the presence of this growth factor (Tables X and XI). Addition of IL- $1 \alpha$ or IL-6 did not alter this trend, all IL-3-containing cultures being composed of about $50 \%$ basophils by $3 \mathrm{wk}$ and retaining significant numbers of basophils throughout the duration of culture.

The cellular composition of hematopoietic colonies assayed from aliquots of the suspension cultures was comparable to those assayed from the original sorted populations with a few notable exceptions. Blast cell colonies, as well as HPPCFC-derived colonies, were routinely obtained by directly assaying $\mathrm{CD}^{2} 4^{+} \mathrm{DR}{ }^{-} \mathrm{CD} 15^{-}$or $\mathrm{CD} 34^{+} \mathrm{DR}^{-} \mathrm{CD} 71^{-}$cells while these colony types were not observed in subsequent clonal assays of cellular aliquots obtained from the long-term liquid cultures. Distribution of GM colony subtypes, however, remained fairly consistent with roughly $40 \%$ being granulocytemacrophage, $40 \%$ monocyte-macrophage, and $20 \%$ basophil or eosinophil colonies in either assays initiated with sorted cells of those initiated on days 7 through 42 of liquid culture.

Table II. Cellular Composition of Sorted Cell Populations

\begin{tabular}{|c|c|c|c|c|c|c|c|c|c|}
\hline Population & Blasts & Myelo & MM & Band & Seg & Baso & Lymph & Norm & Mo \\
\hline & & & & & $\%$ & & & & \\
\hline $\mathrm{CD} 34^{+} \mathrm{DR}^{-}$ & 65.0 & 0.0 & 13.0 & 0.0 & 21.0 & 1.0 & 0.0 & 0.0 & 0.0 \\
\hline $\mathrm{CD}^{+} 4^{+} \mathrm{DR}^{+}$ & 88.0 & 1.0 & 5.0 & 2.0 & 0.0 & 3.0 & 0.0 & 1.0 & 0.0 \\
\hline $\mathrm{CD}_{34}{ }^{+} \mathrm{DR}^{-} \mathrm{CD} 15^{-}$ & 96.0 & 1.0 & 1.0 & 0.0 & 0.0 & 0.5 & 0.5 & 1.0 & 0.0 \\
\hline $\mathrm{CD} 34^{+} \mathrm{DR}^{-} \mathrm{CD} 15^{+}$ & 36.0 & 10.0 & 40.0 & 10.0 & 2.0 & 0.0 & 0.0 & 2.0 & 0.0 \\
\hline $\mathrm{CD} 4^{+} \mathrm{DR}^{-} \mathrm{CD} 3^{-}$ & 59.0 & 2.5 & 18.0 & 15.5 & 2.5 & 0.0 & 0.0 & 0.0 & 2.5 \\
\hline $\mathrm{CD} 4^{+} \mathrm{DR}^{-} \mathrm{CD} 33^{+}$ & 6.5 & 6.5 & 52.5 & 6.5 & 2.0 & 0.0 & 0.0 & 4.5 & 21.5 \\
\hline $\mathrm{CD} 4^{+} \mathrm{DR}^{-} \mathrm{CD} 1^{-}$ & 91.5 & 2.5 & 4.0 & 0.5 & 0.0 & 0.5 & 0.0 & 1.0 & 0.0 \\
\hline 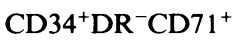 & 82.0 & 1.5 & 5.0 & 1.0 & 1.5 & 0.0 & 0.0 & 7.0 & 0.0 \\
\hline
\end{tabular}

Differential cell counts were performed on Wright-Giemsa stained cytocentrifuge preparations of cells obtained by monoclonal antibody staining and fluorescence-activated cell sorting. 200 cells per slide were classified. Abbreviations: Band, neutrophil band form; Baso, basophils; Lymph, lymphocytes; MM, metamyelocytes; Mo, monocytes; Myelo, myelocytes; Norm, normoblasts; Seg, segmented neutrophils. 
Table III. Hematopoietic Progenitor Cells Present Initially in Sorted Cell Populations

\begin{tabular}{|c|c|c|c|c|}
\hline \multirow[b]{2}{*}{ Population } & \multicolumn{3}{|c|}{ Enumeration at day 14} & \multirow{2}{*}{$\begin{array}{l}\text { Enumeration } \\
\text { at day 28: } \\
\text { HPP-CFC }\end{array}$} \\
\hline & CFU-GM & BFU-E & CFU-GEMM & \\
\hline & \multicolumn{4}{|c|}{ colonies $/ 10^{3}$ cells ${ }^{*}$} \\
\hline $\mathrm{CD} 4^{+} \mathrm{DR}^{-}$ & $26.8 \pm 17.6^{\ddagger}$ & $34.5 \pm 57.0$ & $1.0 \pm 1.4$ & $\mathrm{ND}^{\S}$ \\
\hline $\mathrm{CD}_{34}{ }^{+} \mathrm{DR}^{+}$ & $65.3 \pm 13.5$ & $55.8 \pm 72.6$ & $2.4 \pm 2.8$ & ND \\
\hline $\mathrm{CD}^{2} 4^{+} \mathrm{DR}^{-} 15^{-}$ & $111.0 \pm 18.8$ & $41.5 \pm 4.9$ & $3.3 \pm 0.5$ & $28.0 \pm 2.8$ \\
\hline $\mathrm{CD}^{4} 4^{+} \mathrm{DR}^{-} 15^{+}$ & $24.0 \pm 3.8$ & $0.5 \pm 0.6$ & $0.0 \pm 0.0$ & $0.0 \pm 0.0$ \\
\hline $\mathrm{CD} 4^{+} \mathrm{DR}^{-} \mathrm{CD}^{-} 3^{-}$ & $27.3 \pm 25.6$ & $19.5 \pm 24.1$ & $1.2 \pm 1.9$ & ND \\
\hline $\mathrm{CD} 4^{+} \mathrm{DR}^{-} \mathrm{CD}^{-} 3^{+}$ & $1.2 \pm 1.6$ & $0.0 \pm 0.0$ & $0.0 \pm 0.0$ & ND \\
\hline $\mathrm{CD} 4^{+} \mathrm{DR}^{-} \mathrm{CD} 71^{-}$ & $137.5 \pm 19.6$ & $8.3 \pm 4.4$ & $2.0 \pm 1.8$ & $27.5 \pm 2.1$ \\
\hline $\mathrm{CD}_{3} 4^{+} \mathrm{DR}^{-} \mathrm{CD} 71^{+}$ & $20.8 \pm 3.1$ & $151.3 \pm 2.8$ & $3.3 \pm 2.8$ & $0.0 \pm 0.0$ \\
\hline
\end{tabular}

* $10^{3}$ cells/ml were cultured in methylcellulose with $50 \mathrm{U} / \mathrm{ml} \mathrm{GM-CSF}$ and $1 \mathrm{U} / \mathrm{ml}$ purified human urinary erythropoietin (Toyobo Co., Ltd., Osaka, Japan). ${ }^{\ddagger}$ Each point represents the mean \pm SD of quadruplicate assays or duplicate assays performed on at least two separate occasions. ${ }^{\S}$ Not determined.

These CFU-GM-derived colonies ranged in size from 100 to 2,000 cells with the average colony containing between 200 and 400 cells. After 8 wk of suspension culture, monocytemacrophage colonies were the predominant colony type observed in the clonal assays.

\section{Discussion}

Mammalian hematopoiesis has been studied in vitro through the use of various long-term marrow culture systems (13, 25-27). Dexter and co-workers (13) described a murine system from which CFU-S and CFU-GM could be assayed for several months, with erythroid and megakaryocytic precursors ap-

Table IV. Total Cell Production of CD34 $4^{+}, \mathrm{DR}^{-}, \mathrm{CD} 15^{-}$Cells after Addition of Various Cytokines

\begin{tabular}{lllllllll}
\hline & \multicolumn{8}{c}{ Day } \\
\cline { 2 - 8 } Cytokine & 0 & 7 & 14 & 21 & 28 & 35 & 42 & 56 \\
\hline & \multicolumn{1}{c}{ viable cell count $\times 10^{3}$} \\
\end{tabular}

$\begin{array}{lrrrrrrrr}\text { None } & 5 & 1 & 4 & 0 & 0 & 0 & 0 & 0 \\ \text { IL-1a* }^{*} & 5 & 2 & 2 & 0 & 0 & 0 & 0 & 0 \\ \text { IL-3 }^{\ddagger} & 5 & 53 & 140 & 591 & 1,085 & 533 & 678 & 781 \\ \text { IL-6 }^{\S} & 5 & 3 & 4 & 36 & 26 & 16 & 0 & 0 \\ \text { GM-CSF }^{\prime \prime} & 5 & 8 & 14 & 44 & 169 & 213 & 118 & 0 \\ \text { IL-1 } \alpha / \text { IL-3 }^{\text {G }} & 5 & 32 & 167 & 556 & 1,360 & 1,387 & 758 & 1,069 \\ \text { IL-6/IL-3 } & 5 & 47 & 171 & 471 & 854 & 1,440 & 1,200 & 1,216\end{array}$

Total cells $=$ cells $/ \mathrm{ml}$ culture $/(1 / 2)^{n}$, where $n=$ number of previous demi-depopulations.

* $2.5 \mathrm{U} / \mathrm{ml}$ recombinant human IL-1 $\alpha$ were added every $48 \mathrm{~h}$; specific activity $10^{8} \mathrm{CFU} / \mathrm{mg}$ protein.

$\$ 50 \mathrm{U} / \mathrm{ml}$ recombinant human IL-3 were added every $48 \mathrm{~h}$; specific activity $10^{8} \mathrm{CFU} / \mathrm{mg}$ protein.

$\S 75 \mathrm{U} / \mathrm{ml}$ recombinant human IL-6 were added every $48 \mathrm{~h}$; specific activity $10^{7} \mathrm{CFU} / \mathrm{mg}$ protein.

" $12.5 \mathrm{U} / \mathrm{ml}$ recombinant human GM-CSF were added every $48 \mathrm{~h}$; specific activity $5 \times 10^{7} \mathrm{CFU} / \mathrm{mg}$ protein. pearing for a more limited time. Maintenance of these cultures was dependent on the formation of an adherent stromal cell layer composed of endothelial cells, adipocytes, reticular cells, and macrophages. These methods were soon adapted for the study of human bone marrow. Human long-term culture systems were reported to generate assayable hematopoietic progenitor cells for 8 or $9 \mathrm{wk}(25,26)$ and, later, for up to $20 \mathrm{wk}$ $(27,28)$. Such cultures are again reliant on the preestablishment of a stromal cell layer which is frequently reinoculated with a large, heterogeneous population of marrow cells. Hematopoietic stem cells have been shown to home and adhere to this adherent cell multilayer before generating and releasing more committed progenitor cells $(8,29,30)$. Stromal cells are thought to provide not only a physical matrix on which stem cells reside, but also to produce membrane-contact signals

Table V. Total Cell Production of CD34+ ${ }^{+}, \mathrm{DR}^{-}, C D 71^{-}$Cells after Addition of Various Cytokines

\begin{tabular}{cccccccccc}
\hline & \multicolumn{8}{c}{ Day } \\
\cline { 2 - 9 } Cytokine & 0 & 7 & 14 & 21 & 28 & 35 & 42 & 56 \\
\hline & \multicolumn{4}{c}{ viable cell count $\times 10^{3}$}
\end{tabular}

$\begin{array}{lrrrrrrrr}\text { None } & 5 & 1 & 2 & 0 & 0 & 0 & 0 & 0 \\ \text { IL-1 } \alpha^{*} & 5 & 3 & 0 & 0 & 0 & 0 & 0 & 0 \\ \text { IL-3 }^{\ddagger} & 5 & 40 & 226 & 964 & 746 & 1,190 & 1,120 & 851 \\ \text { IL-6 }^{\S} & 5 & 1 & 2 & 0 & 0 & 0 & 0 & 0 \\ \text { GM-CSF }^{\prime \prime} & 5 & 3 & 34 & 44 & 45 & 445 & 438 & 0 \\ \text { IL- } 1 \alpha / \text { IL-3 } & 5 & 23 & 202 & 684 & 1,112 & 835 & 800 & 1,067\end{array}$

Total cells $=$ cells $/ \mathrm{ml}$ culture $/(1 / 2)^{n}$, where $n=$ number of previous demi-depopulations.

* $2.5 \mathrm{U} / \mathrm{ml}$ recombinant human IL-1 $\alpha$ were added every $48 \mathrm{~h}$; specific activity $10^{8} \mathrm{CFU} / \mathrm{mg}$ protein.

$\ddagger 50 \mathrm{U} / \mathrm{ml}$ recombinant human IL-3 were added every $48 \mathrm{~h}$; specific activity $10^{8} \mathrm{CFU} / \mathrm{mg}$ protein.

$\S 75 \mathrm{U} / \mathrm{ml}$ recombinant human IL-6 were added every $48 \mathrm{~h}$; specific activity $10^{7} \mathrm{CFU} / \mathrm{mg}$ protein.

" $12.5 \mathrm{U} / \mathrm{ml}$ recombinant human GM-CSF were added every $48 \mathrm{~h}$; specific activity $5 \times 10^{7} \mathrm{CFU} / \mathrm{mg}$ protein. 
Table VI. Total CFU-GM Production by CD34 $4^{+}, D R^{-}$, CD15- Cells after Addition of Various Cytokines

\begin{tabular}{|c|c|c|c|c|c|c|c|}
\hline \multirow[b]{2}{*}{ Cytokine } & \multicolumn{7}{|c|}{ Week } \\
\hline & 1 & 2 & 3 & 4 & 5 & 6 & 8 \\
\hline & \multicolumn{7}{|c|}{ CFU-GM/ml culture } \\
\hline None & 40 & 0 & 0 & 0 & 0 & 0 & 0 \\
\hline IL-1 $\alpha^{*}$ & 22 & 14 & 0 & 0 & 0 & 0 & 0 \\
\hline IL-3 ${ }^{\ddagger}$ & 432 & 696 & 591 & 325 & 0 & 0 & 0 \\
\hline IL-6 $6^{\S}$ & 42 & 242 & 96 & 0 & 0 & 0 & 0 \\
\hline GM-CSF ${ }^{\|}$ & 273 & 200 & 219 & 0 & 0 & 0 & 0 \\
\hline IL-1 $\alpha /$ IL-3 & 254 & 397 & 444 & 408 & 139 & 152 & 64 \\
\hline IL-6/IL-3 & 98 & 342 & 236 & 768 & 864 & 1,080 & 384 \\
\hline
\end{tabular}

Total CFU-GM $=$ CFU-GM $/ \mathrm{ml}$ culture $/(1 / 2)^{n}$, where $n=$ number of previous demi-populations.

Cells were seeded at $5 \times 10^{3} / \mathrm{ml}$. CFU-GM in initial (day 0) population $=555 / 5 \times 10^{3}$ cells. Colonies grown in methylcellulose containing $50 \mathrm{U} / \mathrm{ml} \mathrm{GM}-\mathrm{CSF}$ and enumerated after $14 \mathrm{~d}$.

* $2.5 \mathrm{U} / \mathrm{ml}$ recombinant human IL- $1 \alpha$ were added every $48 \mathrm{~h}$; specific activity $10^{8} \mathrm{CFU} / \mathrm{mg}$ protein.

$\ddagger 50 \mathrm{U} / \mathrm{ml}$ recombinant human IL-3 were added every $48 \mathrm{~h}$; specific activity $10^{8} \mathrm{CFU} / \mathrm{mg}$ protein.

$\$ 75 \mathrm{U} / \mathrm{ml}$ recombinant human IL-6 were added every $48 \mathrm{~h}$; specific activity $10^{7} \mathrm{CFU} / \mathrm{mg}$ protein.

" $12.5 \mathrm{U} / \mathrm{ml}$ recombinant human GM-CSF were added every $48 \mathrm{~h}$; specific activity $5 \times 10^{7} \mathrm{CFU} / \mathrm{mg}$ protein.

and/or hematopoietic growth factors necessary for stem cell proliferation and differentiation $(14,17,31,32)$. This heterogeneous mixture of cells comprising the adherent cell layer presents an inherently complex system from which the isola-

Table VII. Total CFU-GM Production by $C D 34^{+}, D R^{-}$, CD71- Cells after Addition of Various Cytokines

\begin{tabular}{lrrrrrrr}
\hline & \multicolumn{7}{c}{ Week } \\
\cline { 2 - 8 } \multicolumn{1}{c}{ Cytokine } & \multicolumn{1}{c}{ CFU-GM/ml culture } \\
& \multicolumn{1}{c}{2} & \multicolumn{1}{c}{3} & \multicolumn{1}{c}{4} & 5 & 6 & 8 \\
None & 15 & 4 & 0 & 0 & 0 & 0 & 0 \\
IL-1 $\alpha^{*}$ & 20 & 0 & 0 & 0 & 0 & 0 & 0 \\
IL-3 & 664 & 272 & 96 & 448 & 119 & 0 & 0 \\
IL-6 $^{\S}$ & 51 & 14 & 0 & 0 & 0 & 0 & 0 \\
GM-CSF $^{\sharp}$ & 402 & 360 & 135 & 28 & 0 & 0 & 0 \\
IL-1 $\alpha /$ IL-3 & 347 & 324 & 342 & 334 & 167 & 240 & 214 \\
& & & & & & &
\end{tabular}

Total CFU-GM $=$ CFU-GM $/ \mathrm{ml}$ culture $/(1 / 2)^{n}$, where $n=$ number of previous demi-populations.

Cells were seeded at $5 \times 10^{3} / \mathrm{ml}$. CFU-GM in initial (day 0 ) population $=690 / 5 \times 10^{3}$ cells. Colonies grown in methylcellulose containing $50 \mathrm{U} / \mathrm{ml} \mathrm{GM}-\mathrm{CSF}$ and enumerated after $14 \mathrm{~d}$.

* $2.5 \mathrm{U} / \mathrm{ml}$ recombinant human IL- $1 \alpha$ were added every $48 \mathrm{~h}$; specific activity $10^{8} \mathrm{CFU} / \mathrm{mg}$ protein.

‡ $50 \mathrm{U} / \mathrm{ml}$ recombinant human IL-3 were added every $48 \mathrm{~h}$; specific activity $10^{8} \mathrm{CFU} / \mathrm{mg}$ protein.

$\S 75 \mathrm{U} / \mathrm{ml}$ recombinant human IL-6 were added every $48 \mathrm{~h}$; specific activity $10^{7} \mathrm{CFU} / \mathrm{mg}$ protein.

" $12.5 \mathrm{U} / \mathrm{ml}$ recombinant human GM-CSF were added every $48 \mathrm{~h}$; specific activity $5 \times 10^{7} \mathrm{CFU} / \mathrm{mg}$ protein.
Table VIII. Assayable CFU-MK in Long-Term Suspension Cultures of $C D 34^{+} D R^{-} C D 71^{-}$Cells Receiving a Combination of $I L-3$ and $I L-6$

\begin{tabular}{cc}
\hline Days in culture $^{*}$ & CFU-MK/ml culture $^{*}$ \\
\hline 7 & $42.6 \pm 7.6^{\S}$ \\
14 & $67.6 \pm 56.6$ \\
21 & $17.0 \pm 11.8$ \\
28 & $20.2 \pm 10.4$ \\
\hline
\end{tabular}

$50 \mathrm{U} / \mathrm{ml}$ recombinant human IL-3 were added every $48 \mathrm{~h}$; specific activity $10^{8} \mathrm{CFUc} / \mathrm{mg}$ protein. $75 \mathrm{U} / \mathrm{ml}$ recombinant human IL-6 were added every $48 \mathrm{~h}$; specific activity $10^{7} \mathrm{CFU} / \mathrm{mg}$ protein.

* Cultures were demi-depopulated every $7 \mathrm{~d}$.

$\ddagger$ CFU-MK were assayed in serum-free fibrin clot culture containing $100 \mathrm{U} / \mathrm{ml} \mathrm{IL-3}$ colonies enumerated at days 18-24 of culture.

${ }^{\S}$ Each point represents the mean \pm SD of triplicate assays. Values are not corrected for the effects of demi-depopulation.

tion of discrete variables affecting stem cell growth has proven difficult.

The use of fluorescence-activated cell sorting has facilitated further characterization of the hematopoietic stem cell in the mouse $(5,6,33,34)$. In humans, monoclonal antibody identification of a number of cell surface antigens has permitted partial phenotypic analysis of the human marrow cell responsible for long-term hematopoiesis $(10,35-37)$. The CD34 antigen, present on $1-4 \%$ of LDBM cells, has been repeatedly demonstrated to be present not only on unipotent and multipotent progenitor cells but their precursors as well $(35,36)$. Cells responsible for the long-term generation of assayable progenitors in marrow culture have been shown by Keating and co-workers (37) to express undetectable quantities of HLA-DR. The data presented here indicate that the cells responsible for long-term in vitro hematopoiesis express the CD34 antigen but not detectable amounts of HLA-DR. The CFU-B1 has also recently been partially phenotyped and shown to be $\mathrm{CD} 34^{+} \mathrm{DR}^{-}$(10). The presence of both cell types responsible for these in vitro functions in the $\mathrm{CD} 34^{+} \mathrm{DR}^{-}$ marrow cell population suggests that they are closely related.

The study of various marrow subpopulations by measure-

Table IX. Total CFU-GM and BFU-E Production by Sorted Cell Populations Stimulated with a Combination of IL-3 and IL-6

\begin{tabular}{|c|c|c|c|c|c|c|}
\hline \multirow[b]{2}{*}{ Population } & \multicolumn{6}{|c|}{ Week } \\
\hline & 1 & 2 & 3 & 4 & 6 & 8 \\
\hline & \multicolumn{6}{|c|}{$C F U-G M(B F U-E) / m l$ culture } \\
\hline $\mathrm{CD}_{34}{ }^{+} \mathrm{DR}^{-} \mathrm{CD} 15^{-}$ & $275(10)$ & $286(4)$ & 64 & 32 & 75 & 0 \\
\hline $\mathrm{CD}_{34}{ }^{+} \mathrm{DR}^{-} \mathrm{CD} 15^{+}$ & $7(1)$ & 26 & 0 & 0 & 0 & 0 \\
\hline $\mathrm{CD} 4^{+} \mathrm{DR}^{-} \mathrm{CD} 71^{-}$ & $220(5)$ & $330(4)$ & 132 & 18 & 43 & 0 \\
\hline $\mathrm{CD}_{34}{ }^{+} \mathrm{DR}^{-} \mathrm{CD} 71^{+}$ & 13 & 16 & 0 & 0 & 0 & 0 \\
\hline
\end{tabular}

Total $\mathrm{CFU}=\mathrm{CFU} / \mathrm{ml}$ culture $/(1 / 2)^{n}$, where $n=$ number of previous demi-depopulations. $50 \mathrm{U} / \mathrm{ml}$ recombinant human IL-3, specific activity $10^{8} \mathrm{CFU} / \mathrm{mg}$ protein and $75 \mathrm{U} / \mathrm{ml}$ recombinant human IL-6, specific activity $10^{7} \mathrm{CFU} / \mathrm{mg}$ protein were added every $48 \mathrm{~h}$. Cells were seeded at $5 \times 10^{3} / \mathrm{ml}$. 
Table X. Differential Analysis of $C D 34^{+}, D R^{-}, C D 15^{-}$Cells after Addition of Various Cytokines

\begin{tabular}{|c|c|c|c|c|c|c|c|c|c|c|c|}
\hline Cytokine & Day & Blasts & Pro & Myelo & MM & Band & Seg & Eo & Baso & E & Mo \\
\hline & & & & & & $\%$ & & & & & \\
\hline Control & 7 & 100 & & & & & & & & & \\
\hline \multirow{2}{*}{ IL-1 $\alpha^{*}$} & 7 & 100 & & & & & & & & & \\
\hline & 14 & 78 & & & & & & & & & 22 \\
\hline \multirow[t]{4}{*}{ IL-6 ${ }^{\ddagger}$} & 7 & 100 & & & & & & & & & \\
\hline & 14 & 27 & 11 & & 9 & & 13 & & 38 & & 2 \\
\hline & 21 & 9 & & & 48 & 2 & 7 & & 17 & & 17 \\
\hline & 28 & & & & 30 & & 4 & & & & 66 \\
\hline \multirow[t]{6}{*}{ GM-CSF } & 7 & 25 & 24 & & 27 & 3 & 21 & & & & \\
\hline & 14 & 9 & 1 & & 46 & 3 & 21 & & 13 & & 7 \\
\hline & 21 & 3 & 2 & 1 & 62 & 3 & 5 & & 22 & & 2 \\
\hline & 28 & 6 & & 1 & 43 & 7 & 3 & & 6 & 2 & 32 \\
\hline & 35 & & & 4 & & & & & & & 96 \\
\hline & 42 & & & 1 & & & & & & & 99 \\
\hline \multirow[t]{6}{*}{ IL-3" } & 7 & 21 & 44 & & 35 & & & & 1 & & \\
\hline & 14 & 7 & 7 & & 53 & & & & 33 & & \\
\hline & 21 & 8 & & & 44 & & & & 48 & & \\
\hline & 28 & 5 & & & 35 & 3 & 9 & & 35 & & 13 \\
\hline & 35 & 2 & & & 16 & 5 & 20 & & 25 & & 32 \\
\hline & 42 & & & & 15 & & 2 & & 20 & & 63 \\
\hline \multirow[t]{7}{*}{ IL-1 $\alpha /$ IL-3 } & 7 & 1 & 5 & 1 & 53 & 12 & 14 & & 14 & & \\
\hline & 14 & 5 & & & 34 & 9 & & & 52 & & \\
\hline & 21 & 1 & & & 53 & 4 & 3 & & 31 & & 8 \\
\hline & 28 & 1 & & & 42 & 12 & 5 & & 32 & & 8 \\
\hline & 35 & & & & 20 & & & & 27 & & 53 \\
\hline & 42 & & & & 8 & & & & 8 & & 84 \\
\hline & 56 & & & & & & & & 11 & & 89 \\
\hline \multirow[t]{6}{*}{ L-6/IL-3 } & 7 & 19 & 26 & 2 & 40 & 5 & 4 & & 4 & & \\
\hline & 14 & 2 & 2 & & 46 & 3 & 1 & & 46 & & \\
\hline & 21 & 5 & 1 & & 37 & 1 & 7 & & 48 & & 1 \\
\hline & 28 & 4 & 1 & & 37 & 10 & 8 & & 35 & & 5 \\
\hline & 42 & 1 & & & 8 & & 1 & & 9 & & 81 \\
\hline & 56 & & & & 2 & & & & 3 & & 95 \\
\hline
\end{tabular}

Differential cell counts were performed on Wright-Giemsa stained cytocentrifuge preparations of cells removed from liquid culture. 200 cells per sample were classified; if $<200$ cells appeared on a slide, all were classified. Abbreviations: E, erythrocytes; Eo, eosinophils; Pro, promyelocytes; other abbreviations as in Table II. $* 2.5 \mathrm{U} / \mathrm{ml}$ recombinant human IL- $1 \alpha$ were added every $48 \mathrm{~h}$; specific activity $10^{8} \mathrm{CFU} / \mathrm{mg}$ protein. ${ }^{\ddagger} 50 \mathrm{U} / \mathrm{ml}$ recombinant human IL-3 were added every $48 \mathrm{~h}$; specific activity $10^{8} \mathrm{CFU} / \mathrm{mg}$ protein. $\$ 75 \mathrm{U} / \mathrm{ml}$ recombinant human IL-6 were added every $48 \mathrm{~h}$; specific activity $10^{7} \mathrm{CFU} / \mathrm{mg}$ protein. " $12.5 \mathrm{U} / \mathrm{ml}$ recombinant human GM-CSF were added every $48 \mathrm{~h}$; specific activity $5 \times 10^{7} \mathrm{CFU} / \mathrm{mg}$ protein.

ment of their hematopoietic cellular output provides an alternative method of characterizing primitive multipotential hematopoietic progenitor cells. Irradiated stromal cultures recharged with $\mathrm{CD} 34^{+} \mathrm{DR}^{+}$cells contained more than twice the number of supernatant cells and a significantly greater number of CFU-GM than parallel cultures recharged with $\mathrm{CD} 34^{+} \mathrm{DR}^{-}$ cells after 7-10 d. Cells expressing both CD34 and HLA-DR have previously been demonstrated to contain the majority of hematopoietic progenitor cells present in human marrow (38). By 14-20 d, however, the CD34 ${ }^{+} \mathrm{DR}^{-}$cultures had surpassed their $\mathrm{CD} 34^{+} \mathrm{DR}^{+}$counterparts in ability to generate hematopoietic cells, suggesting the presence of a more quiescent progenitor with higher proliferative capacity within the $\mathrm{CD} 34^{+} \mathrm{DR}^{-}$population.

The almost total absence of CD33-positive cells in the $\mathrm{CD}^{+} 4^{+} \mathrm{DR}^{-}$subpopulation is consistent with the reports of Andrews et al. $(39,40)$, who demonstrated the absence of CD33 on the precursors of colony-forming cells. Removal of cells expressing the CD15 antigen from the CD34 ${ }^{+} \mathrm{DR}^{-}$population eliminated virtually all of the contaminating, differentiated granulocytic cells. The presence of the CD71 antigen on actively proliferating cells was exploited in order to select a population of quiescent $\mathrm{CD} 34^{+} \mathrm{DR}{ }^{-}$cells. The $\mathrm{CD} 34^{+} \mathrm{DR}{ }^{-} \mathrm{CD} 15^{-}$and $\mathrm{CD} 34^{+} \mathrm{DR}{ }^{-} \mathrm{CD} 71^{-}$populations contained HPP-CFC, a primitive, quiescent cell capable in the mouse of differentiating into several lineages and possessing in vivo repopulating potential (41). Based upon the data presented here, human marrow cells expressing CD34 but not CD33, HLA-DR, CD15, or CD71 antigens share many biological properties that would likely be associated with human hematopoietic stem cells. Such cell populations are quiescent, capable of initiating long term hematopoiesis and generating HPP-CFC-derived colonies in vitro and represent only about $0.01 \%$ of nucleated marrow cells.

During the $8 \mathrm{wk}$ of observation in the stroma-free suspen- 
Table XI. Differential Analysis of CD34+ ${ }^{+}, \mathrm{R}^{-}, C D 71^{-}$Cells after Addition of Various Cytokines

\begin{tabular}{|c|c|c|c|c|c|c|c|c|c|c|c|}
\hline Cytokine & Day & Blasts & Pro & Myelo & MM & Band & Seg & Eo & Baso & $\mathbf{E}$ & Mo \\
\hline & & & & & & $\%$ & & & & & \\
\hline \multirow[t]{2}{*}{ Control } & 7 & 90 & & & & & & & & & 10 \\
\hline & 14 & 40 & & & & & & & & & 60 \\
\hline IL-1 $\alpha^{*}$ & 7 & 82 & & & & & & & & & 18 \\
\hline \multirow[t]{2}{*}{ IL-6 ${ }^{\ddagger}$} & 7 & 43 & 4 & & & & & & & & 13 \\
\hline & 14 & 33 & 20 & & & & & & & & 47 \\
\hline \multirow[t]{6}{*}{ GM-CSF } & 7 & 39 & 33 & & 9 & 5 & 6 & & 5 & & 2 \\
\hline & 14 & 18 & 5 & & 42 & 3 & 12 & & 20 & & \\
\hline & 21 & 4 & & 1 & 66 & 9 & 7 & & & & 4 \\
\hline & 28 & 2 & & & 61 & 3 & 1 & 8 & & & 24 \\
\hline & 35 & 14 & & & 18 & 8 & 8 & 9 & & & 52 \\
\hline & 42 & & & & & & & & & & 100 \\
\hline \multirow[t]{6}{*}{ IL-3" } & 7 & 52 & 40 & & 1 & 2 & 2 & & 2 & 1 & \\
\hline & 14 & 29 & 26 & & 26 & 2 & 3 & & 14 & & \\
\hline & 21 & 13 & 4 & 2 & 28 & 2 & 3 & & 48 & & \\
\hline & 28 & 14 & 3 & & 35 & 5 & 1 & & 35 & & 7 \\
\hline & 35 & 9 & & & 20 & 7 & 6 & & 27 & & 31 \\
\hline & 42 & 2 & & & 5 & & 4 & & 16 & 2 & 71 \\
\hline \multirow[t]{7}{*}{ IL-1 $\alpha / \mathrm{IL}-3$} & 7 & 48 & 42 & & 6 & 2 & 1 & & 2 & & \\
\hline & 14 & 4 & 1 & & 53 & 4 & 5 & & 33 & & \\
\hline & 21 & 3 & & & 44 & 1 & 1 & & 49 & & 2 \\
\hline & 28 & 21 & 3 & & 34 & 4 & 3 & 1 & 27 & & 8 \\
\hline & 35 & 3 & & & 23 & 4 & 29 & & 20 & & 21 \\
\hline & 42 & 1 & & & 7 & 3 & 3 & & 16 & & 70 \\
\hline & 56 & & & & & & 1 & & 8 & & 91 \\
\hline
\end{tabular}

Differential cell counts were performed on Wright-Giemsa stained cytocentrifuge preparations of cells removed from liquid culture. 200 cells per sample were classified; if $<200$ cells appeared on a slide, all were classified. Abbreviations as in Tables II and X. * $2.5 \mathrm{U} / \mathrm{ml}$ recombinant human IL-1 $\alpha$ were added every $48 \mathrm{~h}$; specific activity $10^{8} \mathrm{CFU} / \mathrm{mg}$ protein. ${ }^{\ddagger} 50 \mathrm{U} / \mathrm{ml}$ recombinant human IL-3 were added every $48 \mathrm{~h}$; specific activity $10^{8} \mathrm{CFU} / \mathrm{mg}$ protein. $\$ 75 \mathrm{U} / \mathrm{ml}$ recombinant human IL-6 were added every $48 \mathrm{~h}$; specific activity $10^{7} \mathrm{CFU} / \mathrm{mg}$ protein. $\quad 112.5$ $\mathrm{U} / \mathrm{ml}$ recombinant human GM-CSF were added every $48 \mathrm{~h}$; specific activity $5 \times 10^{7} \mathrm{CFU} / \mathrm{mg}$ protein.

sion system, an adherent cell layer was never observed and sustained proliferation in these cultures was entirely dependent upon the addition of cytokines. One can infer from such data that an important function of the adherent cell layer is the secretion of a number of hematopoietic growth factors. Human stromal cell lines have been shown to produce cytokines including GM-CSF, G-CSF, IL-6, but not IL-3 $(16,42)$. It is therefore intriguing that IL-3 alone or especially in combination with IL-1 or IL- 6 has been shown in this report and that of others (43) to best promote the proliferation of primitive hematopoietic progenitor cells. IL-3 appears to be exclusively produced by $T$ cells and is presently thought not to be a product of marrow stromal cells. The ST-1 stromal fibroblastoid cell line and several murine adipocyte lines that have been utilized by a number of investigators to study cytokine production by marrow stromal elements apparently do not produce IL-3 mRNA $(16,44)$. Such cell lines do not necessarily reflect the capacity of all stromal cell types to produce IL-3. It remains possible that a rare but important stromal cell subtype may secrete IL-3. An alternative explanation is that another cytokine distinct from IL-3 but possessing similar biological activity may be produced by marrow stromal cells and provide under physiological conditions, similar functions to IL-3 (44).

The maintenance of hematopoiesis in vitro for $8 \mathrm{wk}$ in the absence of an adherent cell layer should not lead to conclu- sions that stromal cell-derived matrix proteins or cell-cell interactions are not important in sustaining in vivo or in vitro hematopoiesis. Further dissection of this complex system will be required to identify the importance of these stromal components. Gualtieri et al. (45) have shown that after in vitro irradiation, colony-stimulating activity elaborated by such stromal cell layers was markedly increased, while Alberico et al. (18) have provided evidence that GM-CSF is one cytokine responsible for this postirradiation effect. GM-CSF alone was capable in our studies of sustaining hematopoiesis in suspension culture alone for only 3 or 4 wk. Although GM-CSF is likely an important cytokine elaborated by those stromal cell cultures, its limited ability to sustain long-term hematopoiesis alone suggests that additional cytokines, matrix proteins, or cellular interactions are necessary for more prolonged cell production within the marrow microenvironment.

IL-3 is thought to be necessary both for the continued proliferation of hematopoietic multipotential cells (46) and for the continued viability of cells that reside in $G_{0}$ and/or $G_{1}$ phase of the cell cycle (47). IL-3 alone was able to sustain hematopoiesis in the suspension culture system for 4 or $5 \mathrm{wk}$, while combinations of IL- 1 or IL- 6 and IL- 3 extended hematopoietic activity to $8 \mathrm{wk}$. The prolongation of the period of quantifiable hematopoiesis by these combinations of cytokines is consistent with the hypothesis that such cytokine combina- 
tions actually are affecting a more primitive precursor cell of hematopoietic progenitor cells than are influenced by IL-3 alone $(48,49)$. Ikebuchi et al. (48) have shown that IL-6 synergizes with IL- 3 probably by shortening the $G_{0}$ period of murine stem cells and that the synergistic activity of IL-6 is stronger than that of IL- $1 \alpha$. Leary et al. (50) have confirmed this synergistic action of IL-6 with IL-3 in the human system by documenting the earlier appearance of blast cell colonies in the presence of both growth factors than in the presence of IL-3 alone. They were, however unable to demonstrate a synergistic effect of IL-1 with IL-3 in promoting human blast cell colony formation. In our studies IL-1 and IL- 6 were both effective in enhancing the action of IL-3. The action of IL-1 in potentiating the function of IL-3 may be directly on the primitive hematopoietic multipotential cells as suggested by Stanley et al. (49) and Moore and Warren (51), or perhaps may be due to an indirect effect involving marrow accessory cells. This potential indirect action of IL-1 has been suggested to be in part mediated by IL- 6 by Leary and co-workers $(50)$. It remains possible that the cytokines or cytokine combinations tested in this report do not provide the optimum environment for the propagation long term in vitro hematopoiesis. Further assessment of additional cytokines alone or combinations will be necessary to determine the most efficient humoral environment.

The presence of significant numbers of basophils in suspension cultures containing IL-3 alone or in combination with IL- 1 and IL- 6 indicates the capability of IL-3 to promote basophil development. The induction of basophilic differentiation by IL-3 has been previously demonstrated in vivo in primates by Mayer et al. (52) and in vitro in marrow suspension cultures by Valent et al. (53).

In addition to its ability to enhance IL-3-dependent proliferation of stem cells, human IL-6 is known to be capable alone of supporting the development of murine granulocyte and monocyte progenitors (54). This effect of IL-6 was observed to a limited degree in the presently utilized suspension cultures. IL-6 alone was able to support granulocytic and monocytic differentiation for a limited time. IL- $1 \alpha$ is known to induce various cell types to elaborate other cytokines, among them IL-6, and to potentiate the direct actions of other cytokines (16). The inability of IL-1 alone to promote the proliferation or differentiation of $\mathrm{CD}^{+} 4^{+} \mathrm{DR}^{-} \mathrm{CD} 15^{-}$or $\mathrm{CD} 34^{+} \mathrm{DR}^{-} \mathrm{CD} 71^{-}$ cells is consistent with the findings of others that indicate that this cytokine alone has no colony stimulating ability $(23,55)$.

In the present studies BFU-E were generated for 2 or 3 wk in the suspension cultures. In most human long-term marrow culture systems, the duration of erythropoiesis is far exceeded by that of granulopoiesis and monocytopoiesis $(32,56)$. The etiology of the defect in long-term erythropoiesis in the suspension system described here and in other long-term marrow culture systems containing adherent cell layers is only now being unraveled $(15,32)$.

The suspension culture system utilized in the present studies provides a new investigative tool to explore the biological behavior of primitive multipotential hematopoietic precursor cells. Utilizing highly enriched populations of primitive hematopoietic stem cells, factors influencing hematopoiesis may be isolated and studied. In this way, cytokine and extracellular matrix requirements as well as selective cell-cell interactions necessary for development of the human hematopoietic stem cell might be better ¿xamined and defined.

\section{Acknowledgments}

We wish to thank Stephanie McGillem for secretarial assistance during the preparation of this manuscript.

This work was supported by grants from the National Cancer Institute.

\section{References}

1. Fauser, A. A., and H. A. Messner. 1979. Identification of megakaryocytes, macrophages, and eosinophils in colonies of human bone marrow containing neutrophilic granulocytes and erythroblasts. Blood. 53:1023-1034.

2. Morstyn, G., N. A. Nicola, and D. Metcalf. 1980. Purification of hematopoietic progenitor cells from human marrow using a fucosebinding lectin and cell sorting. Blood. 56:798-806.

3. Ash, R. C., R. A. Detrick, and E. D. Zanjani. 1981. Studies of human pluripotential hemopoietic stem cells. Blood. 58:309-316.

4. Mazur, E. M., R. Hoffman, and E. Bruno. 1981. Regulation of human megakaryocytopoiesis: an in vitro analysis. J. Clin. Invest. 68:733-741.

5. Visser, J. W. M., J. G. J. Bauman, A. H. Mulder, J. F. Eliason, and A. M. DeLeeuw. 1984. Isolation of murine pluripotent hemopoietic stem cells. J. Exp. Med. 59:1576-1590.

6. Spangrude, G. J., S. Heimfeld, and I. L. Weissman. 1988. Purification and characterization of mouse hematopoietic stem cells. Science (Wash. DC). 24:58-62.

7. Leary, A. G., and M. Ogawa. 1987. Blast cell colony assay for umbilical cord blood and adult bone marrow progenitors. Blood. 69:953-956.

8. Gordon, M. Y., C. R. Dowding, G. P. Riley, and M. F. Greaves. 1987. Characterization of stroma-dependent blast colony-forming cells in human marrow. J. Cell. Physiol. 130:150-156.

9. Rowley, S. D., S. J. Sharkis, C. Hattenburg, and L. L. Sensenbrenner. 1987. Culture from human bone marrow of blast progenitor cells with an extensive proliferative capacity. Blood. 69:804-808.

10. Brandt, J. E., N. Baird, L. Lu, E. Srour, and R. Hoffman. 1988. Characterization of a human hematopoietic progenitor cell capable of forming blast cell containing colonies in vitro. J. Clin. Invest. 82:1017-1027.

11. Nakahata, T., and M. Ogawa. 1982. Hemopoietic colonyforming cells in umbilical cord blood with extensive capability to generate mono- and multipotential hemopoietic progenitors. J. Clin. Invest. 70:1324-1328.

12. Humphries, R. K., A. C. Eaves, and C. J. Eaves. 1981. Self-renewal of hemopoietic stem cells during mixed colony formation in vitro. Proc. Natl. Acad. Sci. USA. 78:3629-3633.

13. Dexter, T. M., T. D. Allen, and L. G. Lajtha. 1977. Conditions controlling the proliferation of haematopoietic stem cells in vitro. $J$. Cell. Physiol. 91:335-344.

14. Roberts, R. A., E. Spooncer, E. K. Parkinson, B. I. Lord, T. D. Allen, and T. M. Dexter. 1987. Metabolically inactive 3T3 cells can substitute for marrow stromal cells to promote the proliferation and development of multipotent hematopoietic stem cells. J. Cell. Physiol. 132:203-214.

15. Coulombel, L., M. H. Vuillet, C. Leroy, and G. Tchernia. 1988. Lineage and stage-specific adhesion of human hematopoietic progenitor cells to extracellular matrices from marrow fibroblasts. Blood. 71:329-334.

16. Yang, Y.-C., S. Tsai, G. C. Wong, and S. C. Clark. 1988. Interleukin-1 regulation of hematopoietic growth factor production by human stromal fibroblasts. J. Cell. Physiol. 134:292-296.

17. Eliason, J. F., B. Thorens, V. Kindler, and P. Vassalli. 1988. The roles of granulocyte-macrophage colony-stimulating factor and interleukin-3 in stromal cell-mediated hemopoiesis in vivo. Exp. Hematol. 16:307-312.

18. Alberico, T. A., J. N. Ihle, C.-M. Liang, H. E. McGrath, and 
P. J. Quesenberry. 1987. Stromal growth factor production in irradiated lectin-exposed long-term murine bone marrow cultures. Blood. 69:1120-1127.

19. Sieff, C. A. 1987. Hematopoietic growth factors. J. Clin. Invest. 79:1549-1557.

20. Strauss, L. C., R. K. Stuart, and C. I. Civin. 1983. Antigenic analysis of hematopoiesis. I. Expression of the My-1 granulocyte surface antigen on human marrow cells and leukemic cell lines. Blood. 61:1222-1231.

21. Sieff, C., D. Bicknell, G. Caine, J. Robinson, G. Lam, and M. F. Greaves. 1982. Changes in cell surface antigen expression during hemopoietic differentiation. Blood. 60:703-713.

22. McNiece, I. K., F. M. Stewart, D. M. Deacon, D. S. Temeles, K. M. Zsebo, S. C. Clark, and P. J. Quesenberry. 1989. Detection of a human CFC with a high proliferative potential. Blood. 74:609-612.

23. Bruno, E., R. Briddell, and R. Hoffman. 1988. Effect of recombinant and purified hematopoietic growth factors on human megakaryocyte colony formation. Exp. Hematol. 16:371-377.

24. Vindelov, L. L., I. J. Christensen, and N. I. Nissen. 1983. A detergent-trypsin method for the preparation of nuclei for flow cytometric DNA analysis. Cytometry. 3:323-327.

25. Moore, M. A. S., and A. P. C. Sheridan. 1979. Pluripotent stem cell replication in continuous human, prosimian, and murine bone marrow culture. Blood Cells. 5:297-311.

26. Hocking, W. G., and D. W. Golde. 1980. Long-term human bone marrow cultures. Blood. 56:118-124.

27. Gartner, S., and H. S. Kaplan. 1980. Long-term culture of human bone marrow cells. Proc. Natl. Acad. Sci. USA. 77:4756-4759.

28. Slovick, F. T., C. N. Abboud, J. K. Brennan, and M. A. Lichtman. 1984. Survival of granulocytic progenitors in the nonadherent and adherent compartments of human long-term marrow cultures. Exp. Hematol. 12:327-338.

29. Coulombel, L., A. C. Eaves, and C. J. Eaves. 1983. Enzymatic treatment of long-term human marrow cultures reveals the preferential location of primitive hematopoietic progenitor in the adherent layer. Blood. 62:291-297.

30. Gordon, M. Y., J. A. Hibben, S. Dowding, E. C. GordonSmith, and J. M. Goldman. 1985. Separation of human blast progenitors from granulocytic, erythroid megakaryocytic, and mixed colonyforming cells by "panning" on cultured marrow-derived stromal layers. Exp. Hematol. 13:937-940.

31. Li, C. L., and G. R. Johnson. 1985. Stimulation of multipotential, erythroid and other murine hematopoietic progenitor cells by adherent cell lines in the absence of detectable multi-CSF (IL-3). $\mathrm{Na}$ ture (Lond.). 316:633-636.

32. Tsai, S., C. A. Sieff, and D. G. Nathan. 1986. Stromal cell-associated erythropoiesis. Blood. 67:1418-1426.

33. Johnson, G. R., and N. A. Nicola. 1984. Characterization of two populations of CFU-S fractionated from mouse fetal liver by fluorescence activated cell sorting. J. Cell. Physiol. 118:45-52.

34. Lord, B. I., and E. Spooncer. 1986. Isolation of haematopoietic spleen colony forming cells. Lymphokine Res. 5:59-72.

35. Andrews, R. G., J. W. Singer, and I. D. Bernstein. 1986. Monoclonal antibody 12-8 recognizes a 115-kd molecule present on both unipotent and multipotent colony-forming cells and their precursors. Blood. 67:842-845.

36. Strauss, L. C., S. D. Rowley, V. F. LaRussa, S. J. Sharkis, R. K. Stuart, and C. I. Civin. 1986. Antigenic analysis of hematopoiesis. V. Characterization of My-10 antigen expression by normal lymphohematopoietic progenitor cells. Exp. Hematol. 14:878-886.

37. Keating, A., J. Powell, M. Takahashi, and J. W. Singer. 1984. The generation of human long-term marrow cultures from marrow depleted of Ia (HLA-DR) positive cells. Blood. 64:1159-1162.

38. Lu, L., D. Walker, H. E. Broxmeyer, R. Hoffman, W. Hu, and E. Walker. 1987. Characterization of adult human hematopoietic progenitors highly enriched by two-color sorting with My10 and major histocompatibility class II monoclonal antibodies. J. Immunol. 139:1823-1829.

39. Andrews, R. G., M. Takahashi, G. M. Segal, J. S. Powell, I. D.
Bernstein, and J. W. Singer. 1986. The L4F3 antigen is expressed by unipotent and multipotent colony-forming cells but not by their precursors. Blood. 68:1030-1035.

40. Andrews, R. G., J. W. Singer, and I. D. Bernstein. 1989. Precursors of colony-forming cells in human can be distinguished from colony forming cells by expression of the CD33 and CD34 antigens and light scatter properties. J. Exp. Med. 169:1721-1731.

41. Hodgson, G. S., T. R. Bradley, and J. M. Radley. 1983. In vitro production of CFU-S and cells with erythropoiesis repopulating ability by 5-fluorouracil treated bone marrow. Int. J. Cell Cloning. 1:49.

42. Andrews, D. F., J. Nemunaitis, C. Tompkins, and J. W. Singer. 1989. Effect of 5-azacytidine on gene expression in marrow stromal cells. Mol. Cell. Biol. 9:2748-2751.

43. Kobayashi, M., B. H. Van Leeuwen, S. Elsbury, M. E. Martinson, I. G. Young, and A. J. Hapel. 1989. Interleukin-3 is significantly more effective than other colony-stimulating factors in long-term maintenance of human bone marrow-derived colony forming cells in vitro. Blood. 73:1836-1841.

44. Kodama, H.-A., H. Hagiwara, H. Suda, Y. Amagai, T. Yokota, N. Arai, and Y. Kitamura. 1986. MC3T3-G2/PA6 preadipocytes support in vitro proliferation of hematopoietic stem cells through a mechanism different from that of interleukin 3. J. Cell. Physiol. 129:20-26.

45. Gualtieri, R. J., R. K. Shadduck, D. G. Baker, and P. J. Quesenberry. 1984. Hematopoietic regulatory factors produced in longterm murine bone marrow cultures and the effect of in vitro irradiation. Blood. 64:516-525.

46. Suda, T., J. Suda, M. Ogawa, and J. N. Ihle. 1985. Permissive role of interleukin 3 (IL-3) in proliferation and differentiation of multipotential hematopoietic progenitors in culture. J. Cell. Physiol. 124:182-190.

47. Kelvin, D. J., S. Chance, M. Shreeve, A. A. Axelrad, J. A. Connolly, and D. McLeod. 1986. Interleukin 3 and cell cycle progression. J. Cell. Physiol. 127:403-409.

48. Ikebuchi, K., G. C. Wong, S. C. Clark, J. N. Ihle, Y. Hirai, and M. Ogawa. 1987. Interleukin 6 enhancement of interleukin 3-dependent proliferation of multipotential hemopoietic progenitors. Proc. Natl. Acad. Sci. USA. 84:9035-9039.

49. Stanley, E. R., A. Bartocci, D. Patinkin, M. Rosendaal, and T. R. Bradley. 1986. Regulation of very primitive, multipotent, hemopoietic cells by hemopoietin-1. Cell. 45:667-674.

50. Leary, A. G., K. Ikebuchi, Y. Hirai, G. C. Wong, Y.-C. Yang, S. C. Clark, and M. Ogawa. 1988. Synergism between interleukin-6 and interleukin-3 in supporting proliferation of human hematopoietic stem cells: comparison with interleukin-1 $\alpha$. Blood. 71:1759-1763.

51. Moore, M. A. S., and D. J. Warren. 1987. Synergy of interleukin 1 and granulocyte colony-stimulating factor: in vivo stimulation of stem cell recovery and hematopoitic regeneration following 5-fluorouracil treatment of mice. Proc. Natl. Acad. Sci. USA. 84:7134-7138.

52. Mayer, P., P. Valent, G. Schmidt, E. Liehl, and P. Bettelheim 1989. The in vivo effects of recombinant human interleukin-3: demonstration of basophil differentiation factor, histamine-producing activity, and priming of GM-CSF responsive progenitors in non human primates. Blood. 74:613-621.

53. Valent, P., G. Schmidt, J. Besemer, P. Mayer, G. Zenke, E. Liehl, W. Hinterberger, K. Lechner, D. Maurer, and P. Bettelheim. 1989. Interleukin-3 is a differentiation factor for human basophils. Blood. 73:1763-1769.

54. Wong, G. C., J. S. Witek-Giannotti, P. A. Temple, R. Kriz, C. Ferenz, R. M. Hewick, S. C. Clark, K. Ikebuchi, and M. Ogawa. 1988. Stimulation of murine hemopoietic colony formation by human IL-6. J. Immunol. 140:3040-3044.

55. Ikebuchi, K., J. N. Ihle, Y. Hirai, G. G. Wong, S. C. Clark, and M. Ogawa. 1988. Synergistic factors for stem cell proliferation: further studies of the target stem cells and the mechanism of stimulation by interleukin-1, interleukin-6, and granulocyte colony-stimulating factor. Blood. 72:2007-2014.

56. Harrison, D. E., C. P. Lerner, and E. Spooncer. 1987. Erythropoietic repopulating ability of stem cells from long-term marrow cultures. Blood. 69:1021-1025. 